\title{
Serotonin depletion does not alter lipopolysaccharide-induced activation of the rat paraventricular nucleus
}

\author{
G L Conde, D Renshaw, S L Lightman and M S Harbuz
}

University of Bristol, Division of Medicine, Department of Hospital Medicine, Bristol Royal Infirmary, Marlborough Street, Bristol BS3 8HW, UK

(Requests for offprints should be addressed to M S Harbuz)

\begin{abstract}
We have investigated the effects of serotonin depletion on immune-mediated activation of the hypothalamopituitary-adrenal (HPA) axis. Corticotrophin-releasing factor (CRF) mRNA, c-fos mRNA and Fos peptide responses in the paraventricular nucleus (PVN) together with circulating levels of corticosterone were assessed in response to i.p. injections of three doses of lipopolysaccharide (LPS) both in control animals and animals pretreated with $p$-chlorophenylalanine (PCPA).

Conscious animals received either an i.p. injection of $0.5 \mathrm{ml}$ saline or $200 \mathrm{mg} / \mathrm{kg}$ PCPA in $0.5 \mathrm{ml}$ saline on 2 consecutive days. This treatment resulted in a $93 \%$ depletion of serotonin on the fourth day. On day 4 , animals received i.p. injections of LPS $(2.5 \mathrm{mg} / 0.5 \mathrm{ml}$ saline, $250 \mu \mathrm{g} / 0.5 \mathrm{ml}$ or $50 \mu \mathrm{g} / 0.5 \mathrm{ml}$; E. coli $055: \mathrm{B} 5)$, or saline injections as controls.

Pretreatment with PCPA had no effect on the basal levels of corticosterone, or on the elevated levels induced by the three doses of LPS. Fos peptide and c-fos mRNA were undetectable in control animals, and Fos-like immunoreactivity increased in a dose-
\end{abstract}

dependent manner following i.p. LPS in both control and PCPA-pretreated animals. C-fos mRNA expression induced by LPS was unaffected by serotonin depletion. Following the lowest dose of LPS, CRF mRNA did not change above control levels, however, the medium and high doses of LPS produced a significant $(P<0 \cdot 05)$ increase in CRF mRNA levels in both depleted and intact animals.

To confirm the temporal effects of serotonin depletion on activation of the HPA axis we collected plasma at $30 \mathrm{~min}, 1,2,3,4,5$ and $6 \mathrm{~h}$ after LPS in both intact and serotonin-depleted animals. No significant differences in plasma corticosterone levels were found at any of the time points between intact and depleted animals.

It appears that, at least under these experimental conditions, serotonergic inputs do not seem to play a major role in mediating the effects of LPS on changes in mRNA levels in the PVN or on the subsequent activation of the HPA axis.

Journal of Endocrinology (1998) 156, 245-251

\section{Introduction}

The parvocellular cells of the paraventricular nucleus (PVN) produce corticotrophin-releasing factor (CRF), which is released into the hypophyseal portal blood and is generally considered to be the primary mediator of the stress response. Acute stress is known to activate the hypothalamo-pituitary-adrenal (HPA) axis and results in an increase in CRF mRNA in the PVN, increased plasma adrenocorticotrophin (ACTH) concentrations and hence increased amounts of corticosterone are released from the adrenal glands (Harbuz \& Lightman 1992). Lipopolysaccharide (LPS, a component of the cell wall of gramnegative bacteria) and interleukin-1 $\beta$ (IL-1 $\beta$ ) can induce a wide range of effects, including the activation of the HPA axis (Fontana et al. 1984, Besedovsky et al. 1986, Berkenbosch et al. 1987, Sapolsky et al. 1987, Uehara et al. 1987, Schobitz et al. 1994).
The role played by serotonin in regulating the stress response remains controversial. Serotonergic innervation of the hypothalamus originates in the brainstem raphe nuclei (Moore et al. 1978). It has been suggested that serotonergic innervation of the PVN is very low, compared with surrounding areas (Van de Kar \& Lorens 1979, Sawchenko et al. 1983, Larsen et al. 1996). However, immunocytochemical studies have indicated that contact may exist between CRF immunoreactive cells and serotonin axons, with both axosomatic and axodendritic synapses occurring (Liposits et al. 1987). Acute stress paradigms such as foot-shock result in an increase in serotonin turnover (Dunn 1988). Other studies have suggested that any involvement of serotonin may be stressor dependent, as lesions of the raphe nucleus or direct neurochemical lesions of the PVN have little or no effect on basal or stressinduced changes in plasma corticosterone (Feldman et al. 1987, 1991). In contrast to these acute stressors, little is 
known about the effects of serotonin on acute immune stimulation of the HPA axis by immune modulators such as IL-1 $\beta$ or LPS.

Serotonin release within the brain is known to be affected by IL-1 $\beta$. Intracerebroventricular administration of IL- $1 \beta$ or i.p. LPS both lead to an increase in serotonin and its metabolite 5-hydroxyindoleacetic acid (5-HIAA) within the hippocampus (Mohankumar et al. 1993, Shintani et al. 1993, Linthorst et al. 1994, 1995, 1996). In addition to elevating serotonin levels, intrahippocampal IL-1 $\beta$ also increases HPA axis activity as evidenced by increases in plasma ACTH and corticosterone levels (Linthorst et al. 1994). Immobilization stress elevates plasma ACTH and monoamines including serotonin within the hypothalamus, an effect which can be blocked by the use of an IL-1 receptor antagonist (Shintani et al. 1995). Hence evidence exists suggesting that serotonin could play a role in mediating the effects of IL- $1 \beta$, or LPS on the HPA axis.

The immediate early gene $c$-fos provides a useful means of identifying neuronal activation. Expression is usually very low within the central nervous system (CNS). In response to a stimulus, $c$-fos mRNA appears transiently and rapidly, with peak levels usually being seen at around 30 min to 1 h (Morgan \& Curran 1989), however, following stimulus with an immune mediator such as LPS, c-fos mRNA is high $3 \mathrm{~h}$ following i.p. LPS, declines by $6-9 \mathrm{~h}$ post-injection, and is totally absent $12 \mathrm{~h}$ following i.p. LPS (Rivest \& Laflamme 1995).

In the present study we have depleted serotonin using the reversible tryptophan hydroxylase inhibitor $p$-chlorophenylalanine (PCPA), to determine if this treatment has any effect on the LPS-induced increase in CRF and $c$-fos mRNAs and Fos-like immunoreactivity in the PVN and on plasma concentrations of corticosterone.

\section{Materials and Methods}

Adult male Sprague-Dawley rats weighing 210-250 g were housed four to a cage with free access to food and water. They were maintained on a ratio of $12 \mathrm{~h}$ light: $12 \mathrm{~h}$ darkness (lights on at $0700 \mathrm{~h}$ ). All studies were begun between $0930 \mathrm{~h}$ and $1030 \mathrm{~h}$. On day 1 rats received a single i.p. injection of PCPA (Sigma Chemical Co., Poole, Dorset, UK) at a dose of $200 \mathrm{mg} / \mathrm{kg}$ body weight in a final volume of $0.5 \mathrm{ml}$. Control animals received a similar injection of water. This procedure was repeated on day 2 , and on day 4 animals received an i.p. injection of LPS (E. coli $055: \mathrm{B} 5)$ at a dilution of $2.5 \mathrm{mg} / 0.5 \mathrm{ml}$ saline (high dose), $250 \mu \mathrm{g} / 0.5 \mathrm{ml}$ saline (medium dose) or $50 \mu \mathrm{g} /$ $0.5 \mathrm{ml}$ saline (low dose). Control animals received an i.p. injection of saline. This depletion protocol has previously been demonstrated to result in a greater than $90 \%$ depletion in hypothalamic serotonin (McElroy et al. 1984, Harbuz et al. 1993).
Groups of animals were killed by decapitation either $30 \mathrm{~min}$ ( $n=8$ per treatment group) or $3 \mathrm{~h}(n=8$ per treatment group) following injection. Brains were quickly removed, frozen on dry ice and stored at $-70{ }^{\circ} \mathrm{C}$. Trunk blood was collected into ice-cold heparinized tubes, centrifuged and the plasma stored at $-20{ }^{\circ} \mathrm{C}$ prior to radioimmunoassay.

A second group of animals received an indwelling jugular cannula on day 1 . On days 1 and 2, the animals received either PCPA treatment as described above (depleted, $n=8$ ) or saline (controls, $n=8$ ). On day 4, blood samples were taken from all animals, which then received an i.p. injection of LPS (medium dose, $250 \mu \mathrm{g} / 0.5 \mathrm{ml}$ saline). Blood samples were taken $30 \mathrm{~min}, 1,2,3$, 4, and $5 \mathrm{~h}$ following the LPS injection, centrifuged and the plasma stored at $-20{ }^{\circ} \mathrm{C}$ prior to radioimmunoassay. Animals were killed by decapitation $6 \mathrm{~h}$ following LPS, and trunk blood was collected and treated as described above prior to radioimmunoassay.

\section{In situ hybridization histochemistry (ISHH)}

ISHH was performed as described previously (Harbuz \& Lightman 1989, Harbuz et al. 1993). The probes used were 48-mer oligonucleotides complimentary to part of the exonic mRNA sequences coding for CRF or $c$-fos (bases 138-185) (Perkin Elmer, Norwalk, CT, USA). The specificity of the CRF probe has been previously determined (Young et al. 1986) and representative photomicrographs have been previously published (Lightman \& Young 1988, Harbuz et al. 1991). The specific activities of the CRF and $c$-fos probes (d.p.m. $/ \mathrm{mol}$ ) were $8.65 \times 10^{18}$ and $6.46 \times 10^{18}$ respectively. All control and experimental sections were hybridized in the same hybridization reaction. The autoradiographic images of probe bound to parvocellular CRF mRNA or $c$-fos mRNA, together with ${ }^{14} \mathrm{C}$-labelled standards (to compensate for the non-linear response of the film to radioactivity) were measured using a computer assisted image analysis system (Image 1.22 developed by W Rasband, NIH, Bethesda, MD, USA) and run on an Apple Mac IICi. The CRF results are presented as the mean percentage change from control with a standard error about the mean. The $c$-fos data are presented as actual values with a standard error about the mean.

\section{Immunohistochemistry (IHC)}

IHC was performed as described previously (Conde et al. 1995) but on unfixed frozen $12 \mu \mathrm{m}$ cryostat sections. Sections through the PVN were fixed in 4\% paraformaldehyde for $10 \mathrm{~min}$ prior to immunostaining. The antibody used was a polyclonal rabbit anti-Fos (Oncogene Science, Cambridge, MA, USA, 1:1000) raised against the Nterminal (4-17) region of the rat Fos peptide. Sections 
from all groups of animals were processed simultaneously, and immunoreactive nuclei were counted using a Leitz D M R B microscope.

\section{Radioimmunoassay}

Total plasma corticosterone was measured directly in plasma ( $1 \mu \mathrm{l}$ diluted in $100 \mu \mathrm{l}$ buffer) using antiserum kindly supplied by G Makara (Institute of Experimental Medicine, Budapest, Hungary). The tracer was $\left[{ }^{125} \mathrm{I}\right]$ corticosterone (ICN Biomedicals, Irvine, CA, USA) with a specific activity of $2-3 \mathrm{mCi} / \mu \mathrm{g}$. The sensitivity of the assay was $25 \mathrm{ng} / \mathrm{ml}$.

\section{HPLC}

In order to confirm the extent of the serotonin depletion, $700 \mu \mathrm{m}$ tissue punches were taken from the cerebellum. Serotonin and its metabolite were measured as described previously (Kilpatrick et al. 1986), and protein content was assessed using Pierce protein reagent (Pierce and Warrinder, Chester, UK).

\section{Statistics}

Statistical analysis was carried out using one way analysis of variance (ANOVA) followed by Fisher's PLSD (parametric least significant difference).

\section{Results}

PCPA resulted in a highly significant $(P<0 \cdot 05)$ depletion in serotonin concentrations in the brain compared with saline-injected control rats. Control levels were $71.9 \pm$ $16 \cdot 1 \mathrm{ng} / \mathrm{g}$ wet weight. Levels in PCPA-treated rats were reduced to $5 \cdot 1 \pm 3 \cdot 1 \mathrm{ng} / \mathrm{g}$. This level of depletion (93\%) is in accord with previous studies using similar protocols (McElroy et al. 1984, Harbuz et al. 1993).

Basal plasma corticosterone levels were unaffected by PCPA treatment (Fig. 1). Intraperitoneal injection of all three doses of LPS resulted in a significant $(P<0 \cdot 05)$ increase in plasma corticosterone $3 \mathrm{~h}$ following the injection. This increase was unaffected by serotonin depletion with PCPA.

CRF mRNA in the PVN (Figs 2 and 3) was not significantly altered by PCPA treatment, compared with vehicle-injected animals. Injection of the medium and high doses of LPS caused a significant $(P<0 \cdot 05)$ and similar increase in CRF mRNA, in both vehicle-treated controls and serotonin-depleted animals. Injection of the lowest dose of LPS did not evoke an increase in CRF mRNA levels from controls.

Levels of $c$-fos mRNA were undetectable in all control animals and PCPA treatment itself did not induce $c$-fos mRNA (Figs 4 and 5). Injection of LPS did not induce any

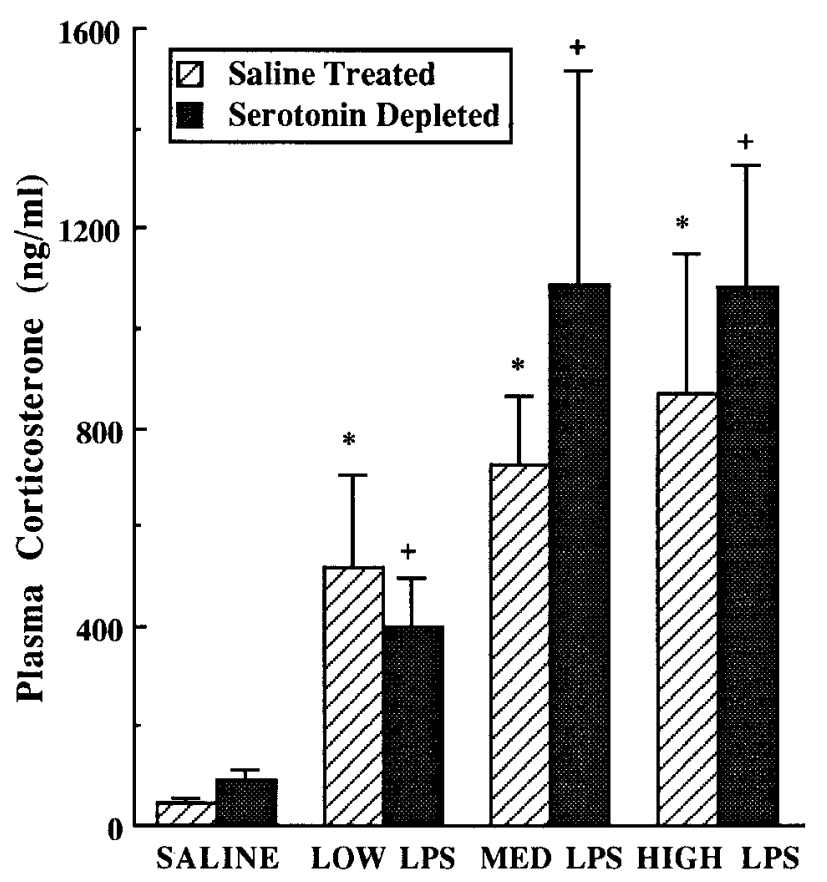

Figure 1 Plasma corticosterone levels $3 \mathrm{~h}$ following i.p. injection of either saline (S) or LPS (L) in intact $(S+S, n=8 ; S+L, n=8)$ or serotonin-depleted ( $\mathrm{P}+\mathrm{S}, n=8 ; \mathrm{P}+\mathrm{L}, n=8)$ animals (means \pm S.E.M.). With all doses of LPS there was a significant increase in plasma corticosterone levels ( ${ }^{*}$ or,$+ P<0 \cdot 05$; Fisher's PLSD). Serotonin depletion had no significant effect on the LPS-induced increase in plasma corticosterone, compared with non-depleted animals.

change in c-fos mRNA at the 30 min time point (data not shown), however, $3 \mathrm{~h}$ after the highest dose of LPS, there was a significant increase in $c$-fos message in the PVN. This increase was similar following serotonin depletion. The low and medium doses of LPS did not result in measurable levels of $c$-fos mRNA in any of the groups of animals studied.

Fos peptide was found to be present in all groups of animals examined, although control groups showed very few Fos-immunoreactive nuclei per section. Fos-positive cells in the PVN increased significantly $(P<0.05)$ with increasing doses of LPS, with the highest number of nuclear profiles being seen in the animals receiving the highest dose of LPS (Fig. 6). This effect was also apparent in the PCPA-treated animals, and serotonin depletion did not significantly alter the numbers of positive cells, except in the group of animals which received the medium dose of LPS. Here, serotonin depletion resulted in a significant $(P<0.05)$ decrease in the numbers of Fos-immunoreactive nuclear profiles, compared with non-depleted animals which had received the same dose of LPS.

In the second study the medium dose of LPS caused a significant increase $(P<0 \cdot 01$, Fisher PLSD) in plasma corticosterone levels within $30 \mathrm{~min}$ of injection, in both intact and serotonin-depleted animals (Fig. 7). Corticosterone 


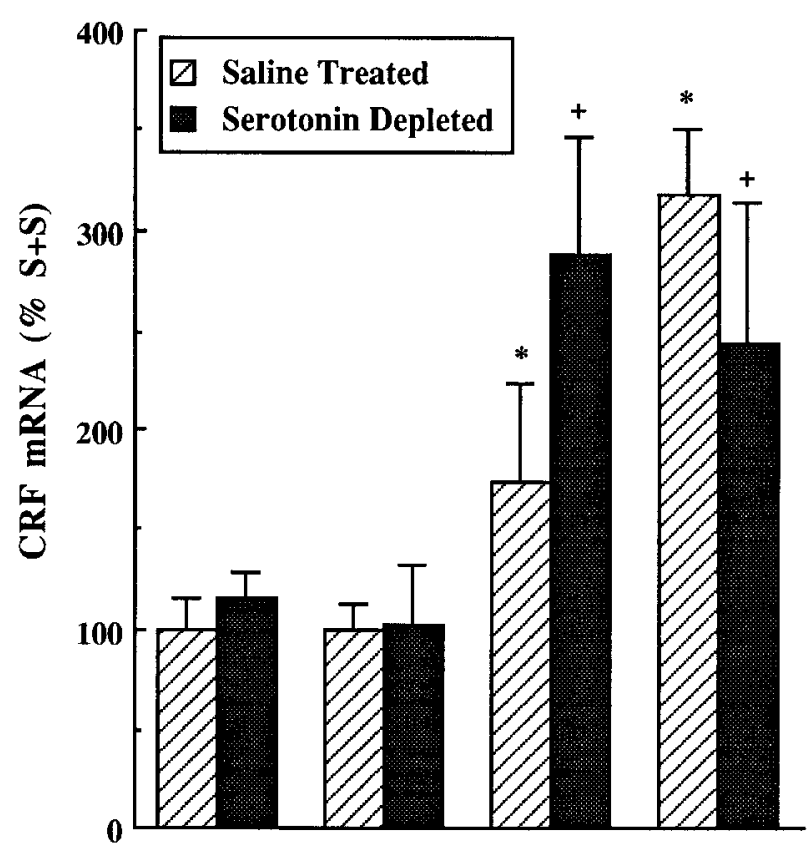

SALINE LOW LPS MED LPS HIGH LPS

Figure 2 CRF mRNA levels in the PVN, expressed as \% of controls $(S+S)$ (means \pm S.E.M.). With the low dose of LPS there was no change in CRF mRNA levels. However following the medium and high doses, CRF mRNA increased significantly ( ${ }^{*}$ or,$+ P<0 \cdot 05$; Fisher's PLSD), compared with the saline-treated controls. Serotonin depletion did not significantly affect this increase.

levels continued to rise reaching a maximum $2 \mathrm{~h}$ following LPS injection, and remaining significantly $(P<0 \cdot 01$; Fisher's PLSD) elevated up to $6 \mathrm{~h}$ following the LPS injection. Depletion of serotonin did not have any significant effect on this increase at any of the time points measured.

\section{Discussion}

We have confirmed that in control animals, c-fos mRNA levels are undetectable in the PVN, indicating very low basal levels of expression (Harbuz et al. 1993). In addition, minor procedures, such as i.p. injection of vehicle had no effect on $c$-fos mRNA levels. In response to i.p. LPS, activation of $c$-fos mRNA was not apparent $30 \mathrm{~min}$ after injection, as would be expected for acute stress, such as restraint stress which produces a peak in $c$-fos mRNA after 30 min (McElroy et al. 1984, Harbuz et al. 1993) and which has all but disappeared by $1 \mathrm{~h}$. C-fos mRNA was present $3 \mathrm{~h}$ following the i.p. injection of LPS within both the magno- and parvocellular portions of the PVN. This expression was unaffected by PCPA-induced depletion of serotonin. Serotonin depletion did not alter the numbers of neurons within the PVN which were immunoreactive for Fos-like peptide $3 \mathrm{~h}$ following i.p. saline, and these control
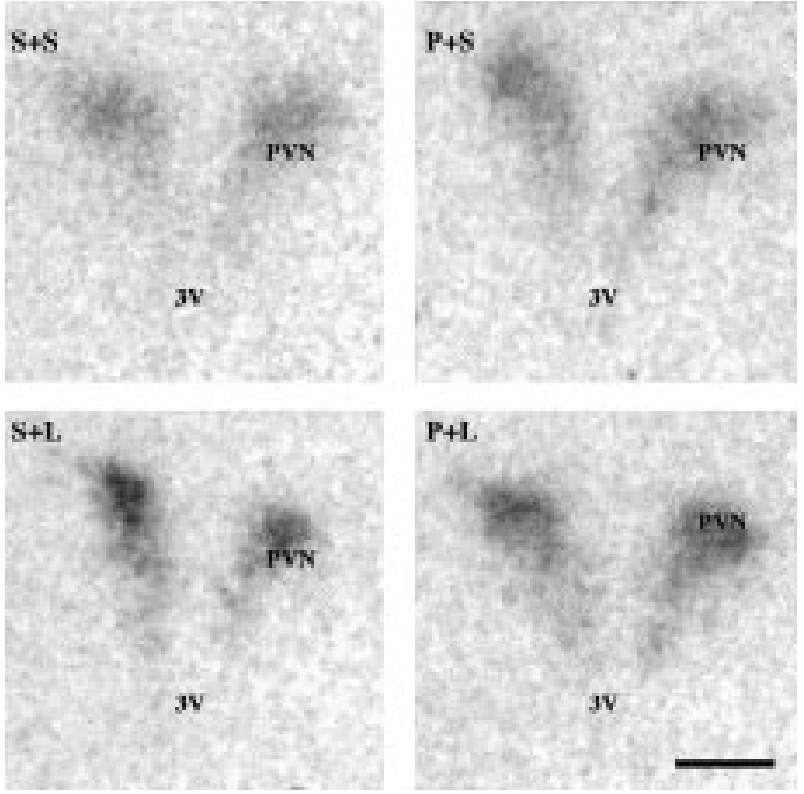

Figure 3 Representative autoradiographs showing CRF mRNA in the PVN in controls $(\mathrm{S}+\mathrm{S})$, depleted animals $(\mathrm{P}+\mathrm{S})$, and controls and depleted animals which had received an i.p. injection of the highest dose of $\mathrm{LPS}$ ( $\mathrm{S}+\mathrm{L}$ and $\mathrm{P}+\mathrm{L}$ respectively), $3 \mathrm{~h}$ prior to killing. $3 \mathrm{~V}$, third ventricle; $\mathrm{Bar}=200 \mu \mathrm{m}$.

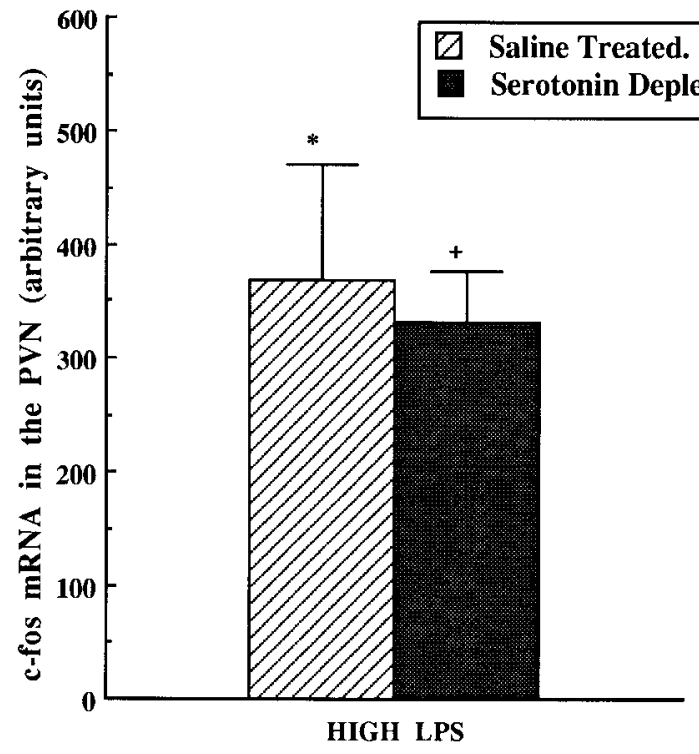

Figure $4 \mathrm{C}$-fos mRNA in the PVN (means \pm S.E.M.) $3 \mathrm{~h}$ following i.p. LPS (high dose). In control animals which had not received LPS, c-fos mRNA was below the level of detection. However, following LPS, there is a significant increase $\left({ }^{*}\right.$ or,$+ P<0 \cdot 01$; Fisher's PLSD) in $c$-fos mRNA compared with controls, with serotonin depletion having no effect on this LPS-induced expression.

animals exhibited few Fos-positive nuclear profiles. Treatment with LPS induced a dose-dependent increase in Fos-positive cells within the PVN. This response was 

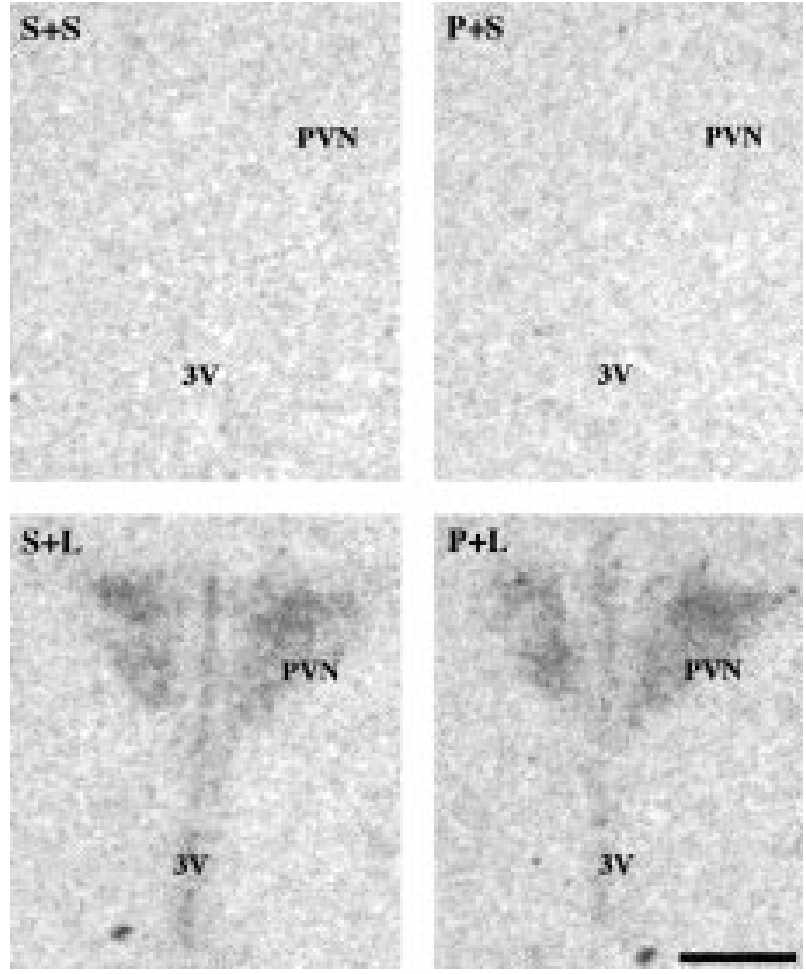

Figure 5 Representative autoradiographs showing c-fos mRNA in the PVN in controls $(S+S)$, serotonin-depleted animals $(P+S)$ and animals following LPS treatment $(\mathrm{S}+\mathrm{L} ; \mathrm{P}+\mathrm{L}) .3 \mathrm{~V}=$ third ventricle; Bar $=200 \mu \mathrm{m}$.

unaffected by PCPA pretreatment, although the response to the medium dose was reduced. This suggests that serotonin does not play a major role in mediating this $c-$ fos response.

PCPA pretreatment did not affect either basal or LPS-activated CRH mRNA $3 \mathrm{~h}$ after LPS injection. LPS-induced plasma corticosterone secretion, as evidence of end-point activation of the HPA axis, was not altered over a period of $6 \mathrm{~h}$. This suggests that serotonin depletion does not alter the response or the time course of the response of the LPS-induced activation of the HPA axis. We have previously demonstrated that changes seen following acute restraint stress are unaffected by PCPA pretreatment (Harbuz et al. 1993) and other workers have shown that lesions of the raphe nucleus do not alter basal or stress-induced changes in plasma corticosterone (Feldman et al. 1987, 1991). This suggests that HPA axis responses to a variety of stimuli are not altered following serotonin depletion.

When IL-1 $\beta$ is infused into the medio-basal hypothalamus using a push-pull cannula, serotonin and levels of its metabolite 5-HIAA rise, indicating that IL-1 $\beta$ can affect the serotonin system and suggests that serotonin might mediate some of the central actions of IL-1 $\beta$ (Shintani et al. 1993). More recent evidence also indicates that

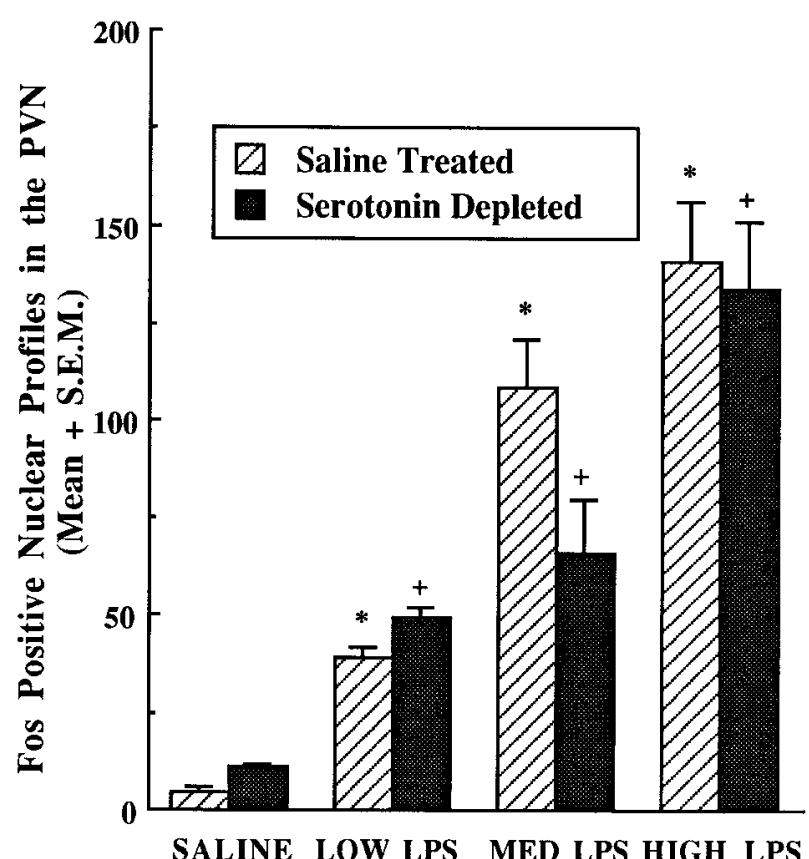

Figure 6 Number of Fos-immunoreactive profiles per section through the PVN (means \pm S.E.M.). Fos peptide was seen in all groups of animals, and increased significantly with increasing doses of LPS $(P<0.05)$, with the highest number being seen in the animals which received the highest dose of LPS. Serotonin depletion did not prevent this increase, although it did attenuate significantly (comparing $\mathrm{S}+\mathrm{L}$ with $\mathrm{P}+\mathrm{L}$ ) the increase seen following the medium dose of LPS ( ${ }^{*}$ or,$+ P<0 \cdot 05$; Fisher's PLSD).

when recombinant human IL-1 $\beta$ is infused into the hippocampus, extracellular serotonin levels are elevated (Linthorst et al. 1994, 1995, 1996). This appears to be in parallel to an increase in the activity of the HPA axis, as plasma ACTH is also elevated. Similar results are obtained using immobilization stress in conjunction with an intrahypothalamic infusion of IL-1 $\beta$ (Shintani et al. 1995). The inference from these studies is of a link between the observed changes in serotonin in response to either LPS or IL-1 $\beta$, and the subsequent activation of the HPA axis. In the present study, our data suggest that these events may occur independently and that under these conditions serotonin does not appear to be involved in mediating the activation of the HPA axis in response to LPS, although serotonin may be involved in mediating the behavioural changes noted following intrahippocampal IL-1 $\beta$ (Linthorst et al. 1996). In contrast to the lack of effects of serotonin on the acute stimulation of the HPA axis by LPS, there is evidence for the involvement of serotonin following chronic immune activation. Adjuvant induced arthritis (AA) is an immune-mediated disease model resulting in hind paw inflammation in susceptible strains of rat, appearing 12-14 days after injection of adjuvant. Associated with the development of inflammation there is an activation of the HPA axis (Harbuz et al. 1992). Depletion 


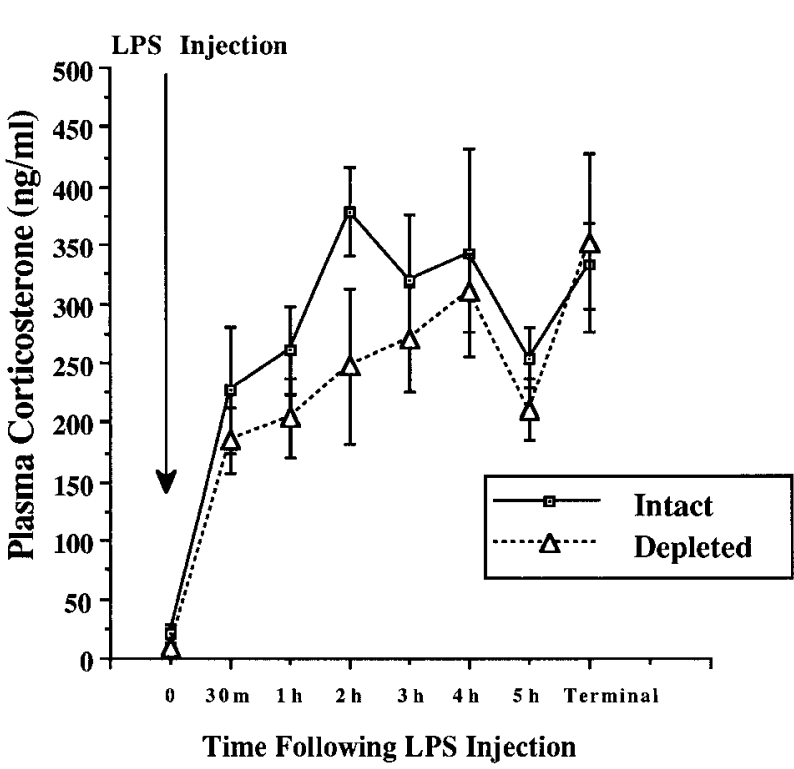

Figure 7 Time course showing plasma corticosterone levels in both serotonin-depleted animals and intact animals $30 \mathrm{~min}, 1,2,3$, 4,5 , and $6 \mathrm{~h}$ following i.p. injection of LPS $(250 \mu \mathrm{l} / 0 \cdot 5 \mathrm{ml}$ saline). LPS causes a significant $(P<0 \cdot 01$; Fisher's PLSD) increase in plasma corticosterone in both depleted and non-depleted animals. There are no differences in plasma corticosterone levels between depleted and non-depleted groups of animals throughout the sampling period.

of serotonin using PCPA at the time of injection of the adjuvant was without effects on the progress of the disease. However, serotonin depletion immediately prior to the onset of inflammation resulted in a significant reduction in the severity of the inflammation (Harbuz et al. 1996). Alterations in the HPA axis associated with inflammation were also reversed in these rats. It appears therefore that serotonin has an important role in modulating the severity of disease and the attendant changes in the HPA axis in this chronic inflammatory stress model.

The tryptophan hydroxylase inhibitor used in the present study, has also been demonstrated to inhibit phenylethanolamine $\mathrm{N}$-methyltransferase, the enzyme responsible for the conversion of noradrenaline to adrenaline (Coen et al. 1993). It is possible therefore that the results obtained here represent the combination of both serotonin and adrenaline depletion. As the role played by adrenaline in controlling the HPA axis is poorly understood, the use of specific lesions and selective antagonists may resolve this issue.

In summary, PCPA pretreatment resulted in a significant decrease in hypothalamic serotonin concentrations. This decrease had no effect on basal levels of corticosterone, nor on levels stimulated by LPS, as ascertained over a considerable period of sampling. Similarly, activation of $c$-fos mRNA and peptide, and of CRF mRNA were unaffected by serotonin depletion. Although serotonin appears to play a relatively important role in mediating chronic inflammatory stress, it does not appear to be involved in modulating the HPA axis response to acute immune activation.

\section{Acknowledgements}

The authors wish to thank Dr Octavi Marti for measuring serotonin levels by HPLC. This work was supported by the Wellcome Trust (grant no. 039863).

\section{References}

Berkenbosch F, van Oers J, Del Rey A, Tilders F \& Besedovsky H 1987 Corticotrophin releasing factor producing neurones in the rat activated by interleukin 1 . Science 238 524-530.

Besedovsky H, Del Rey A, Sorkin, E \& Dinarello CA 1986 Immunoregulatory feedback between interleukin 1 and glucocorticoid hormones. Science 233 652-654.

Coen CW, Coombs MC, Wilson PMJ, Clement EM \& MacKinnon PCB 1993 Possible resolution of a paradox concerning the use of p-chlorophenylalanine and 5-hydroxytryptophan: evidence for a mode of action involving adrenaline in manipulating the surge of luteinizing hormone in rats. Neuroscience 8 583-591.

Conde GL, Bicknell RJ \& Herbison AE 1995 Changing patterns of Fos expression in brainstem catecholaminergic neurones during the rat oestrus cycle. Brain Research 672 68-76.

Dunn AJ 1988 Changes in plasma and brain tryptophan and brain serotonin and of 5-hydroxyindoleacetic acid after footshock stress. Life Sciences 42 1847-1853.

Feldman S, Conforti N \& Melamed E 1987 Paraventricular nucleus serotonin mediates neurally stimulated adrenocortical secretion. Brain Research Bulletin 18 165-168.

Feldman S, Weidenfeld J, Conforti N \& Saphier D 1991 Differential recovery of adrenocortical responses to neural stimuli following administration of 5,7-dihydroxytryptamine into the hypothalamus. Experimental Brain Research 85 144-148.

Fontana A, Weber E \& Dayer J-M 1984 Synthesis of interleukin 1/endogenous pyrogen in the brain of endotoxin-treated mice: a step in fever induction? Journal of Immunology 133 1696-1698.

Harbuz MS \& Lightman SL 1989 Responses of hypothalamic and pituitary mRNA to physiological and psychological stress in the rat. Journal of Endocrinology 122 705-711.

Harbuz MS \& Lightman SL 1992 Stress and the HPA axis: acute, chronic and immune interactions. Journal of Endocrinology 134 327-339.

Harbuz MS, Russell JA, Sumner BEH, Kawata M \& Lightman SL 1991 Rapid changes in the content of proenkephalin A and corticotrophin releasing hormone mRNAs in the paraventricular nucleus during morphine withdrawal in urethane-anaesthetized rats. Molecular Brain Research 9 285-291.

Harbuz MS, Rees RG, Eckland D, Jessop DS, Brewerton D \& Lightman SL 1992 Paradoxical responses of hypothalamic corticotropin-releasing factor (CRF) messenger ribonucleic acid (mRNA) and CRF-41 peptide and adenohypophyseal proopiomelanocortin mRNA during chronic inflammatory stress. Endocrinology 130 1394-1400.

Harbuz MS, Chalmers J, De Souza L \& Lightman SL 1993 Stressinduced activation of CRF and c-fos mRNAs in the paraventricular nucleus are not affected by serotonin depletion. Brain Research 609 167-173.

Harbuz MS, Perveen-Gill Z, Lalies MD, Jessop DJ, Lightman SL \& Chowdrey HS 1996 The role of endogenous serotonin in adjuvantinduced arthritis in the rat. British Journal of Rheumatology 35 $112-116$. 
Kilpatrick I, Jones MW \& Phillipson OT 1986 A semiautomated analysis method for catecholamines, indoleamines, and some prominent metabolites in microdissected regions of the nervous system: an isocratic, HPLC technique employing coulometric detection and minimal sample preparation. Journal of Neurochemistry 46 1865-1876.

Larsen PJ, Hayschmidt A, Vrang N \& Mikkelsen JD 1996 Origin of projections from the midbrain raphe nuclei to the hypothalamic paraventricular nucleus in the rat: a combined retrograde and anterograde tracing study. Neuroscience 70 963-988.

Lightman SL \& Young WS III 1988 Corticotrophin-releasing factor, vasopressin and pro-opiomelanocortin mRNA responses to stress and opiates in the rat. Journal of Physiology 403 511-523.

Linthorst ACE, Flachskamm C, Holsboer F \& Reul JMHM 1994 Local administration of recombinant human interleukin-1 beta in the rat hippocampus increases serotonergic neurotransmission, hypothalamic-pituitary-adrenocortical axis activity, and body temperature. Endocrinology 135 520-532.

Linthorst ACE, Flachskamm C, MullerPreuss P, Holsboer F \& Reul JMHM 1995 Effect of bacterial endotoxin and interleukin-1 beta on hippocampal serotonergic neurotransmission, behavioural activity and free corticosterone levels: an in vivo microdialysis study. Journal of Neuroscience 15 2920-2934.

Linthorst ACE, Flachskamm C, Holsboer F \& Reul JMHM 1996 Activation of serotonergic and noradrenergic neurotransmission in the rat hippocampus after peripheral administration of bacterial endotoxin: involvement of the cyclo-oxygenase pathway. Neuroscience 72 989-997.

Liposits Z, Phelix C \& Paull WK 1987 Synaptic interaction of serotonergic axons and corticotrophin-releasing factor (CRF) synthesizing neurones in the hypothalamic paraventricular nucleus of the rat. Histochemistry 86 541-549.

McElroy JF, Miller JM \& Meyer JS 1984 Fenfluramine, $p$-chloroamphetamine and $p$-fluoroamphetamine stimulation of pituitary-adrenocortical activity in the rat: evidence for differences in site and mechanism of action. Journal of Pharmacology and Experimental Therapeutics 288 593-599.

Mohankumar PS, Thyagarajan S \& Quadri SK 1993 Interleukin-1 beta increases 5 -hydroxyindoleacetic acid release in the hypothalamus in vivo. Brain Research Bulletin 31 745-748.

Moore RY, Halaris AE \& Jones BE 1978 Serotonin neurones of the midbrain raphe: ascending projections. Journal of Comparative Neurology 180 417-438.
Morgan JI \& Curran T 1989 Stimulus-transcription coupling in neurons: role of cellular immediate-early genes. Trends in Neurosciences 12 459-462.

Rivest S \& Laflamme N 1995 Neuronal activity and neuropeptide gene transcription in the brains of immune-challenged rats. Journal of Neuroendocrinology 7 501-525.

Sapolsky R, Rivier C, Yamamoto G, Plotsky P \& Vale W 1987 Interleukin 1 stimulates the secretion of hypothalamic corticotrophin releasing factor. Science 238 522-524.

Sawchenko PE, Swanson LW, Steinbusch HWM \& Verhofstad AAJ 1983 The distribution and cells of origin of serotonergic inputs to the paraventricular and supraoptic nuclei of the rat. Brain Research 277 355-360.

Schobitz B, Sutanto W, Carey MP, Holsboer F \& De Kloet ER 1994 Endotoxin and interleukin 1 decrease the affinity of hippocampal mineralocorticoid (type I) receptor in parallel to activation of the hypothalamo-pituitary-adrenal axis. Neuroendocrinology 60 124-133.

Shintani F, Kanaba S, Nakaki T, Nibuya M, Kinoshita N, Suzuki E, Yagi G, Kato R \& Asai M 1993 Interleukin-1 beta augments release of norepinephrine, dopamine and serotonin in the rat anterior hypothalamus. Journal of Neuroscience 13 3574-3581.

Shintani F, Nakaki T, Kanaba S, Sato K, Yagi G, Kato R \& Asai M 1995 Involvement of interleukin 1 in immobilization stress induced increase in plasma adrenocorticotropic hormone and in release of hypothalamic monoamines in the rat. Journal of Neuroscience $\mathbf{1 5}$ 1961-1970.

Uehara A, Gottschall PE, Dahl RR \& Arimura A 1987 Interleukin 1 stimulates $\mathrm{ACTH}$ release by an indirect action which requires corticotrophin releasing factor. Endocrinology 121 1580-1582.

Van de Kar LD \& Lorens SA 1979 Differential serotonergic innervation of individual hypothalamic nuclei and other forebrain regions by the dorsal and median midbrain raphe nuclei. Brain Research 162 45-54.

Young WS III, Mezey E \& Siegel RE 1986 Quantitative in-situ hybridization histochemistry reveals increased levels of corticotropinreleasing factor mRNA after adrenalectomy in rats. Neuroscience Letters 70 198-203.

Received 2 December 1996

Revised manuscript received 21 March 1997 Accepted 6 May 1997 